khác đối với u lympho thể nang độ 3 nên lựa chọn điêu trị như một u lympho tế bào $\mathrm{B}$ lớn lan tỏa bằng phác đồ RCHOP.

\section{TÀI LIỆU THAM KHẢO}

1. Trân Văn Thuấn. Hướng dẫn chẩn đoán và điều trị bệnh ung thư thường gặp. Nhà xuất bản Y học. 2019:5-24.

2. Arnold S Freedman. Clinical manifestations, pathologic features, and diagnosis of mantle cell lymphoma. Uptodate. 2021:1-14.

3. Andrew D.Z. NCCN Clinical practice guidelines in Oncology - B-Cell lymphomas. NCCN. 2020:12-65.

4. Mondello $\mathbf{P}$. et al. Bendamustine plus rituximab versus R-CHOP as first-line treatment for patients with indolent non-Hodgkin's lymphoma: evidence from a multicenter, retrospective study. Ann
Hematol. 2016;95(7):1107-1114.

5. Takashi Watanabe. Outcomes after R-CHOP in patients with newly diagnosed advanced follicular lymphoma: a 10-year follow-up analysis of the JCOG0203 trial. Lancet Haematol. 2018:520-531.

6. Ganguly Siddhartha, Patel Vijay. R-CHOP versus R-CVP in the treatment of follicular lymphoma: a meta-analysis and critical appraisal of current literature. J Hematol Oncol 2009:14-19.

7. Mondello $\mathbf{P}$. Bendamustine plus rituximab versus R-CHOP as first-line treatment for patients with indolent non-Hodgkin's lymphoma: evidence from a multicenter, retrospective study. Ann Hematol. 2016;(7)(95):1107-1114.

8. Flinn I. W. Randomized trial of bendamustinerituximab or R-CHOP/R-CVP in first-line treatment of indolent NHL or MCL: the BRIGHT study. Blood Journal. 2014;123(19):2944-2952.

\title{
BÁO CÁO TRƯờNG HợP DI VẬT HIẾM GẶP Ở SỤN PHỄU GÂY ÁP XE SỤN PHỄU
}

\section{TÓM TẮT}

Tháng 5/ 2021, bệnh nhân nam, 55 tuổi, nhập viện vì nuốt đau. Bệnh nhân khai có nuốt ăn cá và hóc xương, nuốt đau, ngày càng tăng, ăn uống khó. Nội soi thực quản ống mềm ghi nhận phù nề vùng niêm mạc sụn phễu bên trái và 1 lổ thủng trên niêm mạc. CT'scan vưng cổ ghi nhận thây dị vật cản quang dạng đường thẳng, dài $2,8 \mathrm{~cm}$, nằm trên mức sụn nhẫn. Bệnh nhân được gây mê, nội soi đánh giá vùng hạ họng thanh quản dưới nội soi thấy phù nề vùng xoang lề trái, có 1 lố dò nghi ngờ đường vào của dị vật. Kết hợp nội soi, phẫu thuật viên sử dụng dụng cụ vi phẫu mở rộng đường vào, thám sát đáy vết thương thấy di vật xương cá.

Tư khóa: dị vật xương cá, dị vật ở sụn phễu

\section{SUMMARY \\ RARELY CASE REPORT: FOREIGN BODY OF ARYTENOID CARTILAGE CAUSING ABSCESS}

A 55 years old patient visited to Cho Ray hospital in May, 2021 with painful swallowing. The patient had painful swallowing while he ate fish. He felt pain every swallowing. Result of fexible endoscopy was edema of left arytenoid cartilage mucosa. CTscan shown straight foreign body in arytenoid cartilage with $2.8 \mathrm{~cm}$ length. And then, he was operated to remove foreign body from arytenoid cartilage with general anesthesia. Foreign body was straight, long fish bone.

*Bênhh viên Chơ Rẫy

Chịu trách nhiệm chính: Ngô Văn Công

Email: congtmh@gmail.com

Ngày nhận bài: 15.9.2021

Ngày phản biên khoa học: 15.11.2021

Ngày duyệt bài: 23.11.2021
Ngô Văn Công*

Key words: fish bone foreign body, forgein body in arytenoid cartilage.

\section{GIỚI THIÊUU}

Dị vật đường tiêu hóa trên là một trong những cấp cứu thường gặp của Tai Mũi Họng. Dị vật thực quản thường gặp ở trẻ em và người lớn, trong đó dị vật xương động vật (đặc biệt là xương cá) chiểm ưu thế ở người lớn [1]. Theo hướng dấn dị vật đường ăn của Hội Nội Soi Đường Tiêu Hóa Hoa Kỳ thì dị vật thường đi qua thực quản và ra ngoài theo đường tiêu hóa, khoảng $10-20 \%$ cần can thiệp lấy dị vật qua nội soi và dưới $1 \%$ cần can thiệp phẫu thuật [2]. Di vật thường tắc nghẽn tại những chỗ hẹp sinh lî của thực quản. Các di vật lớn hoăc kích thước bất thường thường gây chèn ép lền niêm mạc thực quản làm phù nề, thiếu máu, hoại tử niêm mạc. Thủng thực quản là biến chứng đe dọa tính mạng và thường thấy ở dị vật sắc nhọn và xương động vật (xương cá). Các biến chứng bao gồm loét thực quản, rách thực quản, thủng thực quản, áp xe do dị vật, ... [6]

\section{BÁO CÁO TRƯỜNG HỢP LÂM SÀNG:}

Bệnh nhân nam, 55 tuổi, nhập viện vì nuốt đau ngày 28 tháng 5 năm 2021. Bệnh nhân khai đã hóc xương cá 1 ngày trước, được khám và chì định nội soi thực quản ống mềm. Kết quả nội soi thực quản ống mềm ghi nhận phù nề vùng xoang lê trái, không ghi nhận dị vật qua nội soi.

Sau đó, bệnh nhân được chỉ định chụp CTscan vùng cổ ghi nhận thấy dị vật cản quang 
dạng đường thẳng, dài $2,8 \mathrm{~cm}$, nằm trên mức sụn nhẫn.

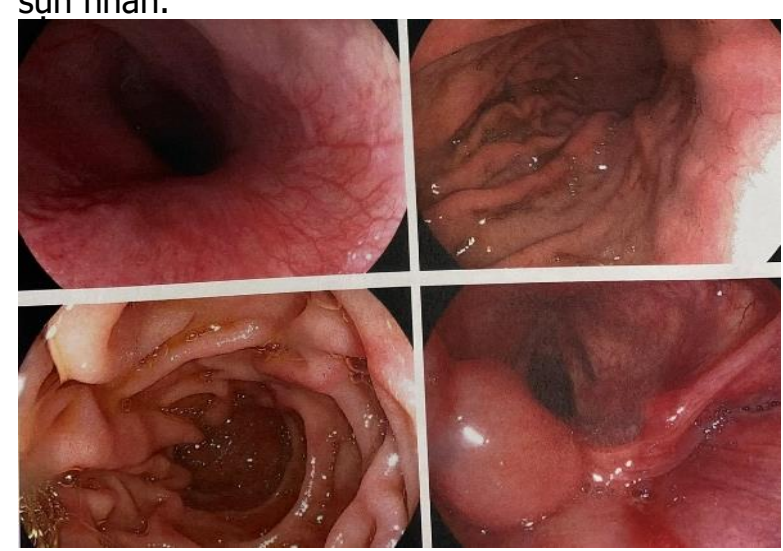

Hình 1.1. Hình ảnh nội soi thực quản ống mềm, ghi nhận phù nề sụn phễu trái, không thây di vật.

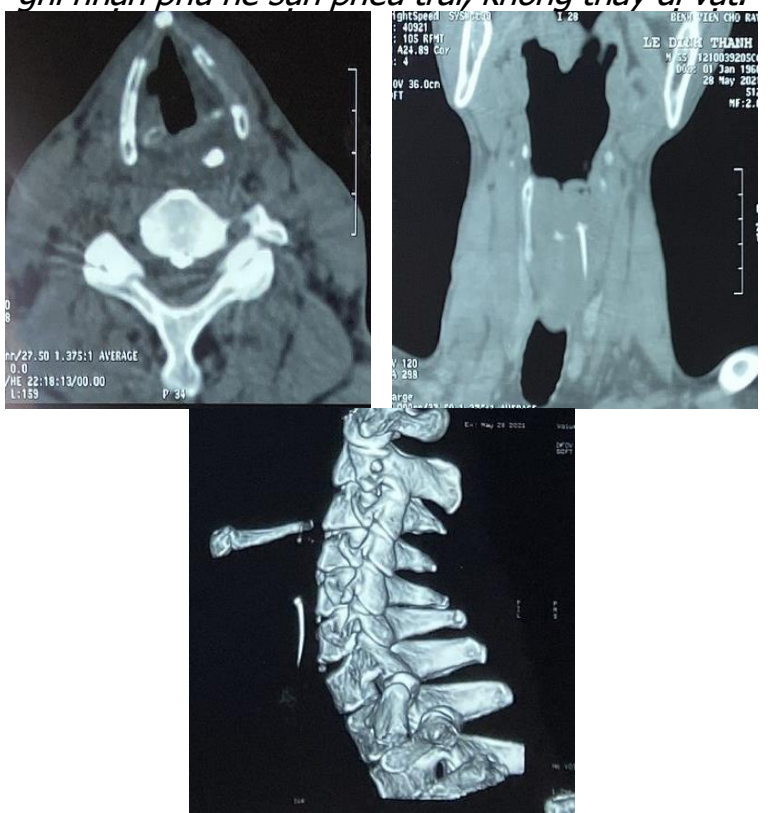

Hình 1.2. CTscan cố (có dựng hình 3D) ghi nhân dị vật dạng xương, nằm trên mức sụn nhẫn, bên trái

Bênh nhân được chỉ định phẫu thuât nội soi thanh thực quản ống cứng lấy dị vật thực quản. Sau khi gây mê toàn thân, phẫu thuật viên tiến hành đánh giá vùng hạ họng thanh quản dưới nội soi thấy phù nề sụn phểu - vùng xoang lê trái, có 1 lố dò nghi ngờ đường vào của dị vật. Kết hợp nội soi, phẫu thuật viên sử dụng dụng cụ vi phẫu mở rộng đường vào, thám sát đáy vết thương thấy dị vật xương cá.

Bệnh nhân được điều trị kháng sinh tĩnh mạch và nuôi ăn qua ống thông mũi dạ dày. Sau 5 ngày, bệnh nhân được rút ống thông mũi dạ dày và ăn uống bình thường.
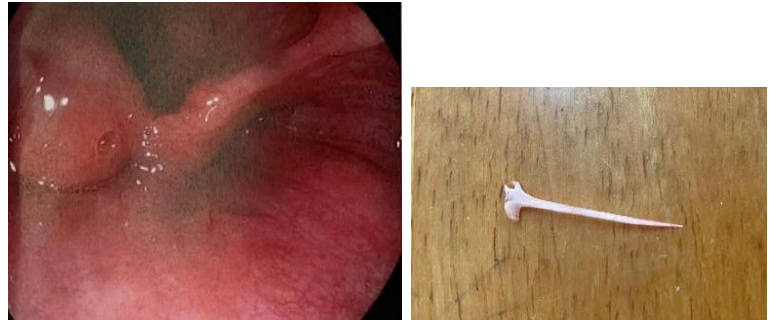

Hình 1.3. Hình ảnh phù nề sụn phễu phải và dị vật xương cá sau khi rạch sụn phễu phải để lấy.

\section{BÀN LUÂN}

Ca lâm sàng trên mô tả trường hợp dị vật thực quản nằm ở vị trí ít gặp - vùng sau sụn nhẫn. Trên lâm sàng, đa số các dị vật đều đi qua ống tiêu hóa ra ngoài mà không gây triệu chứng. Trong một số trường hợp, dị vật thường tắc nghẽn tại những chỗ hẹp sinh lí của thực quản, tùy vị trí tác động mà các triệu chứng lâm sàng có thể thay đổi. Khoảng $2 / 3$ dị vật thực quản nằm ở thực quản trên, đặc biệt ở mức cơ siết họng, là khu vực hẹp nhất [3].

Triệu chứng thường gặp của hốc xương bào gồm nuốt vướng, nuốt đau, khó nuốt, đau nhói mỗi khi nuốt, đây là triệu chứng gợi ý của hốc xương. Cần khám lâm sàng và nội soi kiểm tra. Khi nội soi không thấy xương và không tương ứng với lâm sàng cần khảo sát hình ảnh học thêm để loại trừ dị vật nằm trong mô, che khuất dị vật.

Chụp Xquang cổ thẳng nghiêng với hình ảnh dị vật cản quang, tư khí trong khoang cổ ngực, tràn dịch màng phổi. Các nhà lâm sàng chú ý: không thể loại trừ sự hiện diện của xương cá, xương gà, thủy tinh, gỗ hoặc kim loại mỏng, tỉ lế âm tính giả là $47 \%$ nghi ngờ dị vật và $87 \%$ có khối thức ăn chèn ép xung quanh. Trong trường hợp những dị vật không cản quang (đặc biệt dị vật nhọn), hoặc nghi ngờ có biến chứng, CTscan cổ ngực có cản quang sẽ cung cấp thông tin về bản chất, vị trí dị vật, giải phẫu kế cận dị vật, cũng như các hình ảnh tổn thương liên quản như tụ khí - dịch quanh thực quản, viêm, áp xe, ...[4]. Nguy cơ biến chứng của dị vật nhọn là $35 \%$. Hơn nữa, vùng lân cận là các cơ quan quan trọng, làm tăng nguy cơ tử vong khi có biến chứng [5].

Nội soi thực quản là tiêu chuẩn vàng để chẩn đoán và là phương pháp điều trị phổ biến. Nội soi thực quản ống mềm và ống cứng đều là những phương pháp an toàn và hữu hiệu để lấy các loại dị vật thực quản. Theo Hiệp Hội Nội soi Tiêu hóa Chẩu Âu khuyến nghị nội soi ống mềm là lựa chọn hàng đầu do tiết kiệm chi phí, dung 
nạp tốt, rút ngắn thời gian và có thể thực hiện dưới tiền mê. Trong khi đó, nội soi ống cứng có một số ưu điểm: cơ thực quản được giãn hoàn toàn dưới gây mê, tiếp cận thực quản dễ dàng, đặc biệt là vùng cơ thắt thực quản trên, cung cẩp phẫu trường rộng, thao tác nhiều dụng cụ, đường thở được bảo vệ, phù hợp bệnh nhân không hợp tác (trẻ em)[2].

Việc lựa chọn phương pháp tiếp cận di vật thực quản phụ thuộc các yếu tố liên quan: bệnh nhân (tuổi, tình trạng lâm sàng), dị vật (kích thước, hình dạng, vị trí giải phẫu, phân İoại), kĩ năng của phẩu thuật viên. Theo khuyến cáo Hiệp Hội Nội soi Tiêu hóa Hoa Kì, thời gian dị vật trong thực quản không quá 24 giờ. Thời gian dị vật trong thực quản càng lâu thì nguy cơ hoại tử và thủng thực quản càng cao. Đối với dị vật nhọn (xương, kẹp giấy, câu răng, kim,...) hoặc dị vật có tính ăn mòn (pin) thì cần can thiệp cấp cứu, chú ý nguy cơ hít sặc và thủng thực quản [2].

Trong trường hợp ca lâm sàng này, vị trí của dị vật nằm ở vùng sau sụn nhẫn, trong vách khí thực quản. Đây là vùng hẹp nhất của đường tiêu hóa trên, kế cận thanh khí quản cùng với tình trạng phù nề niềm mạc cho nên nội soi ống mềm lấy dị vật là rất khó thực hiện. Do vậy, chúng tôi tiến hành nội soi ống cứng dưới gây mê toàn thân giúp đảm bảo đường thở và thao tác lấy dị vật dể dàng hơn. Với phẩu trường rộng, hỗ trợ ống nội soi phóng đại và các dụng cụ vi phẫu (kéo, kẹp răng chuột, kẹp cá sấu, kẹp ba chân, ...) giúp xử lí các dị vật (nhọn, tròn, cứng, mềm,..) hoặc kích thước lớn. Tùy vị trí dị vật, phẫu thuật viên cần chọn lựa kích thước ống soi phù hợp để tiếp cận dị vật và giảm thiểu nguy cơ tổn thương niêm mạc, chú ý định hướng dị vật, sử dụng đầu ống bảo vệ niêm mạc.

\section{KẾT LUẬN}

Dị vật thực quản là một tình trạng cấp cứu, cần can thiệp sớm, đặc biệt dị vật tắc nghẽn hoàn toàn, vật nhọn hoặc có tính ẳn mòn trong thực quản. Trong những trường hợp khó, cần kêtt hợp lâm sàng, nội soi, và hình ảnh học (Xquang cổ thẳng, nghiêng và CTscan) để xác định dị vật. Từ đó chọn phương pháp điêu trị thích hợp. Nội soi thực quản ống cứng được thực hiện nếu nội soi ông mềm thất bại hoặc trường hợp có biến chứng.

\section{TÀI LIỆU THAM KHẢO}

1. Ngổ Vương Mỹ Nhân (2008), "Đánh giá kết quả lấy dị vật đường ăn bằng ống nội soi cứng và ông nội soi mềm", Bệnh viện An Giang.

2. Eisen, Glenn M., et al. "Guideline for the management of ingested foreign bodies." Gastrointestinal endoscopy 55.7 (2002): 802-806."

3. Kim J. P., Kwon O. J., Shim H. S., Kim R. B., Kim J. H., Woo S. H. (2015), Analysis of Clinical Feature and Management of Fish Bone Ingestion of Upper Gastrointestinal Tract. Clin Exp Otorhinolaryngol, 8 (3), 261-7.

4. Klein Ayala, Ovnat-Tamir Sharon, Marom Tal, Gluck Ofer, Rabinovics Naomi, Shemesh Shay (2019), Fish Bone Foreign Body: The Role of Imaging. International archives of otorhinolaryngology, $23(1), 110-115$.

5. Feng, Shui, et al. "Management of Sharp-Pointed Esophageal Foreign-Body Impaction With Rigid Endoscopy: A Retrospective Study of 130 Adult Patients." Ear, Nose \& Throat Journal 99.4 (2020): 251-258.

6. Yahyaoui, Salem, et al. "Delayed diagnosis of esophageal foreign body: A case report." International journal of surgery case reports 36 (2017): 179-181.

\section{KẾT QUẢ THẨM MỸ PHẪU THUÂTT TÁI TẠO VÚ BẰNG TÚI ĐộN VÀ CÁC YẾU TỐ LIÊN QUAN}

\section{TÓM TẮT.}

Mục tiêu: Đánh giá kết quả thẩm mỹ phẫu thuật tái tạo vú bằng túi độn và các yếu tố liên quan. Đối tượng và phương pháp nghiên cứu: Mô tả hồi cứu kết hợp tiến cứu trên 51 bệnh nhân ung thư vú được phấu thuật cắt tuyến vú tiết kiệm da hoặc bảo tồn

\section{Bênh viên $K$}

Chịu trách nhiệm chính: Lê Hồng Quang

Email: bslequang@gmail.com

Ngày nhận bài: 10.9.2021

Ngày phản biện khoa học: 12.11.2021

Ngày duyệt bài: 18.11.2021
Lê Hồng Quang ${ }^{1}$

núm kết hợp đặt túi từ tháng 1/2016 - tháng 10/2019 tại khoa Ngoại Vú bệnh viện K. Kết quả: Điểm thẩm mỹ ở mức đẹp và tốt sau mổ 1 tháng, 1 năm, 2 năm lần lượt là $82,4 \% ; 76,5 \% ; 70,5 \%$. Điểm thẩm mỹ sau mổ giảm theo thới gian. Nhóm xa trị bổ trợ và có biến chứng bao xơ có điểm thẩm mỹ thấp hơn nhóm không xạ trị và ko có bao xơ $(p<0,05)$. Kết luận: Tái tạo tuyến vú một thì bằng túi độn cho kết quả thẩm mỹ tốt, có sự suy giảm tính thẩm mỹ theo thời gian và nhóm điều trị xa trị bổ trớ.

Tư khoá: kết quả thẩm mỹ, tái tạo vú, túi độn.

\section{SUMMARY}

AESTHETIC RESULTS OF BREAST 